\title{
restorative justice in papua new guinea: a collaborative effort
}

\begin{abstract}
Ruby Zarriga
of Papua New Guinea's Department of National Planning discusses the link between community development and restorative justice. She also provides examples of how communities have attempted to resolve conflicts and offers some

suggestions as to how agents of change, be it government, church, non-government organisation or development partner, can work through community structures.
\end{abstract}

\section{Community development and restorative justice}

What then is development?

Development is a special type of growth and change that affects communities in many different ways. Community development is a much over-used term that has come to mean all things to all people. We need to have a clear idea of what it means, however, before we can begin to do it. Experience has shown that many so-called community development projects and programs are neither about development nor do they involve the community in a meaningful way. Sometimes the people that work on such projects, often unselfishly and at great personal sacrifice, end up doing more harm than good.

Community development refers to the process by which people and government work together to improve the social, economic and cultural conditions of communities, and integrate these communities into national life and enable them to contribute fully to national progress. A key aspect of this process is about enabling people and communities to determine their own goals and devise appropriate ways of achieving them. 
The goal of community development is to help build a responsible people who are willing and able to use their available resources for their own common good. This is based on the belief that women and men are capable of growing as human beings and that powers of creativity, leadership and goodwill increase as they are exercised. People need to be involved in their own development. Self-help, however, is not enough. Too much emphasis on community self-help seems to imply that all troubles will disappear if only the community helps itself. This is often not the case. Many problems, such as poverty, illiteracy, malnutrition, sickness and disease, are caused by factors originating outside the community, and cannot be changed by the community acting alone. Take a problem like unemployment among school-leavers. Measures can be taken that help alleviate the effects of this problem, but the underlying causes lie in government policies and are often influenced by external and global factors.

Important features of community development include:

- The focus is on the whole community;

- $\quad$ Communities do not develop in isolation but contribute to national progress;

- People should be assisted to develop their human personalities through self-awareness, participation, assuming responsibility and involvement in local affairs;

- Self-help and the use of local initiatives should be encouraged;

- $\quad$ Programs should be built on felt needs as far as this is possible;

- Where external experts are used, their services and skills should be provided at the request of the community and in accordance with expressed community needs.

In community development, it is ultimately more important that the people themselves change than that a particular program or project succeeds. There should be gradual and genuine improvement in general living standards before anyone can conclude that the project or program was successful. 
Attitudes may change towards some things but we must remain mindful that local cultures have developed over many years and have done so in response to particular conditions within their environment. People's culture and values have to be taken into account and respected.

Community development is one among many approaches to development used by government and non-government organisations to discharge responsibilities to people in a variety of locations and situations.

Restorative justice is a way of dealing with conflicts in the community and has the aim of restoring harmony initially between the victim and the offender but ultimately within the community as a whole. It is a process of reconciliation where forgiveness is achieved and the community at large is strengthened.

Different members of the community are involved in this process such as mediators, the offender, the victim and their families. Meetings are held between the different groups and the issues at hand are discussed at length. Compromises are made. In the end, the victim and offender have to fulfil agreed terms and conditions, assisted by their supporters or family groups. The process involves commitment, participation and acceptance of responsibility on the part of the offender, victim and community as a whole.

\section{Restorative justice: an aspect of community development}

Restorative justice can be an important part of the process of community development. It is not only about solving conflicts but, more generally, about improving the well-being of men, women and children within the community and empowering them to better access and use information and basic human services.

The process requires that people make choices about their futures and that their personal skills and capacities are increased. This places them in a stronger position to guide and manage development in their own lives. 
From our discussions, we can see that there are important common elements linking ideas about restorative justice and community development. They are:

Self determination

The community itself decides on what changes should be made. A high degree of motivation among the people (men, women, boys and girls) is required if the changes are to be lasting ones.

\section{Community pace}

Most communities have their own ways and preferred pace for carrying out changes. These have to be learned and respected. Rapid changes imposed from the outside can destroy community cohesion. When people are able to understand and accept small changes, then they are more able to accept big ones.

\section{Participation}

The people must be involved in the whole process. This includes participation in planning at every stage of the proposed program or project. In the case of a dispute, everyone affected by it should be a party to its peaceful resolution.

Starting where the people are

If the people in a community are unwilling to change, they are likely to resist attempts to impose it. Attending to change must start with the community members themselves. Community structures and processes must be understood and respected.

Training of local leadership

A good leader must always know a little more than his or her followers. Local leaders must be adequately trained. Good local leadership will inspire confidence in the program among the wider community.

\section{Community organising}

How does restorative justice apply to Papua New Guinea communities?

While the Melanesian countries are now part of the global economy, traditional community structures and processes remain largely intact although they have been modified to meet 
changing circumstances. These structures are still useful avenues for the mediation of various kinds of conflict.

In Papua New Guinea there are different kinds of community organisations. For example, a rural village may be comprised of three clan or totem groups. In addition, members of these groups may be part of a church within the village.

Under the aegis of government reforms, some members of the community will be members of ward development committees. Local leadership status may be transferred automatically or new appointments made based on particular skills and experiences. These are the types of communities that we find today in rural PNG. Their members have important obligations towards one another and in the general upkeep of the village.

In the urban centres, wantoks, or people coming from the same rural area, may be concentrated in one settlement on the periphery of a town. Alternatively, suburban communities might be made up of people from different ethnic backgrounds. New relationships will be formed if they join the same church, and yet another kind of community will develop. Family ties and the extended family remain an important source of support, providing a social safety net in difficult times.

It is also common in the urban centres to find sporting and fellowship groups forming along provincial or ethnic lines. This is another form of security and support. When special needs arise, as in the case of a death or a marriage, the community will act in a collaborative manner to try and meet them. The spirit of belonging and togetherness is still very much alive in most PNG communities.

Restorative justice is not new to Papua New Guinea's diverse cultures and traditions. Government authorities should give serious consideration to restorative justice as a means for resolving community-based conflicts. There are many customs, traditions, and practices that help maintain peace within communities. The idea of restorative justice fits well with the existing and traditional structures of Papua New Guinea. It needs to be recognised and supported by our political leaders 
and government as an important aspect of development. Greater awareness is required to ensure our leaders appreciate the considerable potential that communities have to bring about positive change for themselves, regardless of whether they are in rural or urban areas.

\section{Examples of resolving conflicts by the community}

\section{Example 1}

This is one example out of many. In May 2000 a bus belonging to a regional Christian leaders' training institution in one of the Highlands provinces of Papua New Guinea ran over a young woman on the Highlands highway on its way to town. The woman, who had run into the path of the bus, was knocked down and died instantly.

In fear of his life and the safety of his passengers, who were mostly workers and students, the driver did not stop but continued into town and reported the matter to the police. For his own protection, the police kept him locked in a cell. Later the police took him back to the college in his own vehicle that had also been locked up at the police station for security reasons. The passengers returned to the college individually in other vehicles.

Meanwhile, the woman's people got in a truck and came to the college. The principal and others at the college did not know what these villagers had in mind. Leaders from the villages within the boundaries of the college met the delegation and, after a long and heated discussion, agreement was reached on a form of preliminary settlement that would contribute towards a peaceful resolution.

Aware of the risk of the conflict escalating, members of the villages within the college boundaries got together and collected K2,000 (AUS\$1,500.00) and then brought the money to the haus lain of the dead woman. This first payment was made to enable further discussion to take place.

The village where the woman had been run over is situated at a place that must be passed by those living within the college boundaries travelling to town. This dispute had to be settled in order to allow free movement to college residents. 
The villagers from both sides went about the business of dispute resolution in their own way, and negotiated their own terms and conditions. By the end of the month, which was the appointed time for payment of compensation, the villagers and the college had organised a payment of K15,000 (reduced from $\mathrm{K} 45,000-\mathrm{K} 50,000)$ in cash and 15 pigs, and this was presented to the haus lain of the deceased. This may sound a little strange to people from other cultures but it was the local way of reaching a peaceful settlement. Communities that had been affected by this incident contributed to its resolution in many different ways. While the compensation in this case was largely in the form of money, it is widely accepted throughout PNG that when a dispute occurs some kind of traditional settlement is necessary.

\section{Example 2}

Conflicts arising within the church are not often dealt with by the formal legal system. For example, where conflicts take place in marriages that were celebrated by the church, or where followers are in conflict with the church leadership, these matters are often referred back to the church to deal with. This suggests that the churches have developed their own ways of restoring peace and harmony in the case of disputes occurring within the church community. Churches have also played an important role in assisting those in conflict in the wider community.

\section{Role of change agents (in restorative justice within communities)}

In the area of community development, the government should work closely with the community to identify what works best in a particular context.

A similar process of consultation and partnership is required in the case of initiatives for change that originate outside the country. For example, in Papua New Guinea, the AusAID-funded Community Development Scheme is working closely with community groups. The United Nations Population Fund is also collaborating with the churches and with individual pastors in the area of family life development in order to assist their work in the community. 
The primary role of an agent of change is to build up people rather than structures. This entails the building of confidence and self-reliance among people who can then proceed to take charge of solving their own problems and ordering of their own lives.

This is a difficult and demanding approach to community development. It requires workers with a particular type of personality and set of skills that are by no means possessed by all. The agency that employs the worker, be it a church, nongovernment organisation or government agency, must be committed to real long-term development. Peace and development must ultimately be achieved by the community itself. Change will only succeed if the community is ready for it and where that change is facilitated through the community's own structures.

There are persons in every community whose talents can be harnessed and utilised. People can be assisted to accept their responsibilities. Learning is most relevant when it is built into and around real life experiences. The most effective venue for learning is within the community itself where members can choose the direction of their own development. They know their problems best and can generally work out the solutions more effectively than outsiders.

Community development is likely to be sustainable when leadership tasks and responsibilities are shared by many people.

\section{Conclusions}

People living in communities already play a central and active role in maintaining peace and resolving local disputes. Restorative justice strengthens the capacities of communities to do this through co-operation and partnership between the various stakeholders.

Community participation in restorative justice increases the likelihood of successful and sustainable resolutions to local incidents of crime and conflict. 